\title{
Effect of grazing pastures with different botanical composition by lambs on rumen fatty acid metabolism and fatty acid pattern of longissimus muscle and subcutaneous fat
}

\author{
M. Lourenço, G. Van Ranst ${ }^{\ddagger}$, S. De Smet, K. Raes and V. Fievez ${ }^{\dagger}$ \\ Laboratory for Animal Nutrition and Animal Product Quality, Department of Animal Production, Ghent University, Proefhoevestraat 10, 9090 Melle, Belgium
}

(Received 27 June 2006; Accepted 16 January 2007)

In order to study the effect of grazing pastures with a different botanical composition on rumen and intramuscular fatty acid metabolism, 21 male lambs were assigned to three botanically different pastures: botanically diverse (BD) (consisting for 65\% of a variety of grass species); Leguminosa rich (L) (consisting for 61\% of Leguminosae) and intensive English ryegrass (IR) (with 69\% Lolium perenne). Pastures were sampled weekly for 12 weeks for analysis of their fatty acid content and composition and on nine occasions to determine the botanical composition. Ruminal and abomasal contents were sampled at slaughter and muscle and subcutaneous fat $24 \mathrm{~h}$ after slaughter. All samples were prepared and analysed for fatty acid composition. The $L$ pasture showed a higher fatty acid content (29.8 mg/g dry matter (DM) v. 18.5 and $25.5 \mathrm{mg} / \mathrm{g} \mathrm{DM}$, for BD and IR pastures, respectively), but the sum of the proportions of the major polyunsaturated fatty acids, C18:2 n-6 and C18:3 n-3, were similar for the three pastures (69.9, 69.4 and $71.1 \%$ of fatty acids methyl esters (FAME) for BD, $L$ and IR pastures, respectively). The BD pasture was richer in C18:2 $n$ 6 (18.2\% of FAME), while IR pasture had a higher C18:3 n-3 content (57.2\% of FAME). Rumen data showed that animals grazing the BD pasture presented higher proportions of biohydrogenation intermediates, mainly C18:1 t11, C18:2 t11c15 and CLA c9t11, suggesting an inhibition of biohydrogenation. These changes were associated with shifts in the rumen microbial population as indicated by differences in the rumen pattern of volatile fatty acids, microbial odd- and branched-chain fatty acids. In $L$ pasture animals, the content of C18:2 n-6 and C18:3 n-3 in the abomasum and subcutaneous fat was higher. Finally, higher proportions of C20:4 n-6, C20:5 n-3 and C22:5 n-3 and higher indices for elongation and desaturation activity in the intramuscular fat of BD grazing animals suggest some stimulation of elongation and desaturation of long-chain fatty acids, although this also might have been provoked partially by reduced fat deposition (due to a lower growth rate of the animals).

Keywords: biohydrogenation, fatty acids, grazing, pastures

\section{Introduction}

Recently, there has been an increased interest in the effects of feeding botanically diverse pastures on the fatty acid (FA) profile of animal tissues as reported by Ådnøy et al. (2005), showing intramuscular polyunsaturated FA (PUFA) content to be higher in lambs grazing diverse mountain compared with monoculture of lowland pastures. Further, Collomb et al. (2001 and 2002a) showed that diverse highland and mountain pastures had a higher potential to stimulate milk conjugated linoleic acid (CLA) secretion than legumes and grasses of the lowland. In some (e.g. Collomb et al., 2001 and

\footnotetext{
${ }^{\dagger}$ Corresponding author. E-mail: veerle.fievez@UGent.be

${ }^{\ddagger}$ Present address: Plant Genetics and Breeding, Institute for Agricultural and Fisheries Research, Caritasstraat 21, 9090 Melle, Belgium
}

2002a) but not all cases (e.g. Collomb et al., 2002b; Lourenço et al., 2005), this could be related to an increased dietary precursor (C18:2 n-6 + C18:3 n-3) supply. Similarly, Cabiddu et al. (2005) showed that sheep milk was richer in CLA when animals grazed a mixture of ryegrass with white clover compared with grazing other legumes mixed with ryegrass, despite the similar proportions of C18:2 n- $6+\mathrm{C} 18: 3 \mathrm{n}-3$ in all diets. From the concomitant accumulation of vaccenic acid (C18:1 t11) in the rumen, Lourenço et al. (2005b) suggested inhibition of some hydrogenating rumen microbes.

Thus, the objectives of this experiment were to study the FA content of three botanically different pastures and to examine whether grazing these pastures resulted in a modified rumen FA metabolism and FA pattern in muscle and subcutaneous fat of lambs. 


\section{Material and methods}

\section{Animals}

Twenty-one male lambs of similar genetic background ('Vlaams Kuddeschaap', a typical 'herding' sheep breed), all born from yearling ewes and originating from an organic farm (Berendrecht, Belgium) were used for this experiment. Until the beginning of the experiment, the lambs were grazing with their mothers on the pastures of the organic farm of origin. At weaning, animals were assigned to one of three pastures, based on their age and live weight ( $n=7$ each), i.e. a botanically diverse (BD), leguminosa rich $(\mathrm{L})$ or intensive English ryegrass (IR) pasture. The average age and live weight at the onset of the experimental period was 86 (s.d. 9) days and 22.3 (s.d. 3.1) $\mathrm{kg}$ respectively, and did not significantly differ between groups.

\section{Pastures}

The experiment was carried out for 12 weeks (1 July 2004 until 22 September 2004). Animals were grazing ad libitum and did not receive any supplemental feed. Essential minerals were provided by a mineral block for sheep (Timac Potasco, Belgium), with the following mineral and microelement composition: sodium $(270 \mathrm{~g} / \mathrm{kg})$, calcium $(60 \mathrm{~g} / \mathrm{kg})$, phosphorus $(2 \mathrm{~g} / \mathrm{kg})$ and magnesium $(1 \mathrm{~g} / \mathrm{kg}))$ and micronutrients (zinc $(18000 \mathrm{mg} / \mathrm{kg})$, manganese $(2000 \mathrm{mg} / \mathrm{kg})$, iodine $(100 \mathrm{mg} / \mathrm{kg})$, cobalt $(40 \mathrm{mg} / \mathrm{kg})$ and selenium $(10 \mathrm{mg} / \mathrm{kg}))$.

The botanical composition of the pastures was determined according to De Vries (1933) on samples taken on nine occasions during the trial. A pooled sample from several sampling squares $\left(100 \mathrm{~cm}^{2}\right)$ was used for the determination. The sampling squares were taken every $15 \mathrm{~m}$ by crossing the fields in zigzag, assuring that also the sides were sampled. Different plants inside the sampling square were identified and numerated by order of frequency. For each species the frequency was calculated and expressed as proportion of all investigated sample sites. In each sampling site, the most predominant species (ranking a) received a score of 3 , the second predominant species (ranking b) 2 and the third (ranking c) a score of 1. All the other species identified were assigned score 0 . Per species $\mathrm{Bi}$ (that represents how many times a species received the ranking $a, b$ and $c$ ) has been calculated as $B=((a) \times 3)+((b) \times 2)+((c) \times 1)$. The relative importance of a species $\left(B_{\text {rel }} i(\%)\right)$ represents how many times a species received the ranking $a, b$ and $c$ and is calculated according to the formula: $B_{\text {rel }} i(\%)=B i l \sum_{i=1}^{j} B i$, with $B i$ as defined before and $j$ the total number of species identified. This determination was made for every sampling. The importance of each individual species over the entire trial period is reported which is the average of the nine calculated $B_{\text {rel }}$ i values. The botanical composition of the different pastures is presented in Table 1.

The $B D$ and $L$ pastures were situated on the farm of origin of the lambs (Berendrecht, Belgium, $51^{\circ} 20^{\prime} \mathrm{N} / 04^{\circ} 28^{\prime} \mathrm{E}$, $14 \mathrm{~m}$ a.s.l.). These pastures were natural grasslands without any kind of fertilisation. The IR pasture was situated at the experimental farm of the Ghent University (Melle, Belgium, $50^{\circ} 59^{\prime} \mathrm{N} / 03^{\circ} 49^{\prime} \mathrm{E}, 11 \mathrm{~m}$ a.s.l.) and was fertilised on 4 May 2004 with $185 \mathrm{~kg} / \mathrm{ha} \mathrm{NH}_{4} \mathrm{NO}_{2} \quad 27 \%$ and $30 \mathrm{~kg} / \mathrm{ha}$ $\mathrm{P}_{2} \mathrm{O}_{5}$; and on 18 August 2004 with $130 \mathrm{~kg} / \mathrm{ha} \mathrm{NH}_{4} \mathrm{NO}_{2}$ $27 \%$. Stocking density was lower than $850 \mathrm{~kg}$ live weight per ha in the BD pasture and lower than $1200 \mathrm{~kg}$ live weight per ha in the $L$ and IR pastures. Height of the pastures was constant at 10 to $15 \mathrm{~cm}$. This was achieved by mowing the fields on the 1st week of August 2004 or by adjusting stocking density when the growth of the pastures became excessive.

\section{Measurements and sampling}

During the experimental period, representative samples of the pastures were taken weekly for dry matter (DM), chemical composition determination and FA analysis. Sampling of the pastures was done according to an adapted technique described by Madeira de Carvalho (2002). Plant material was cut with scissors at a height of approximately $5 \mathrm{~cm}$, every $10 \mathrm{~m}$ when crossing the fields

Table 1 Botanical composition (main species) of the three pastures $(n=9)$

\begin{tabular}{|c|c|c|c|}
\hline \multirow[b]{2}{*}{ Plant family } & \multicolumn{3}{|c|}{ Pasture } \\
\hline & $\mathrm{BD}$ & $\mathrm{L}$ & IR \\
\hline \multirow[t]{3}{*}{ Poaceae } & $\begin{array}{l}\text { Agrostis stolonifera Creeping bentgrass } \\
\qquad(38 \% \pm 5.8)\end{array}$ & $\begin{array}{l}\text { Lolium perenne English ryegrass } \\
\qquad(19 \% \pm 6.6)\end{array}$ & $\begin{array}{l}\text { Lolium perenne English ryegrass } \\
\qquad(69 \% \pm 4.4)\end{array}$ \\
\hline & $\begin{array}{l}\text { Bromus hordeaceus Soft brome } \\
\qquad(18 \% \pm 4.9)\end{array}$ & Phleum pratense Timothy $(14 \% \pm 2.5)$ & $\begin{array}{l}\text { Bromus hordeaceus Soft brome } \\
\quad(17 \% \pm 3.1)\end{array}$ \\
\hline & Phleum pratense Timothy $(9 \% \pm 3.5)$ & & $\begin{array}{l}\text { Lolium multiflorum Italian ryegrass } \\
\qquad(5 \% \pm 2.6)\end{array}$ \\
\hline \multirow[t]{2}{*}{ Asteraceae } & Carduus nutans Thistle $(12 \% \pm 6.6)$ & & \\
\hline & Taraxacum officinale Dandelion $(4 \% \pm 1.7)$ & & \\
\hline Ranunculaceae & Rannunculus acris Buttercup $(5 \% \pm 2.9)$ & & \\
\hline \multirow[t]{2}{*}{ Fabaceae } & & $\begin{array}{l}\text { Trifolium repens White clover } \\
\qquad(41 \% \pm 5.8)\end{array}$ & \\
\hline & & Medicago sativa Lucerne $(20 \% \pm 5.8)$ & \\
\hline
\end{tabular}


on their width and assuring that the sides were also sampled. Thistles were however not cut, as careful observation of the lambs grazing showed animals were not consuming this species. After collection, the fresh samples of each pasture were mixed and a representative sub-sample $(30 \mathrm{~g})$ was stored immediately in liquid $\mathrm{N}_{2}$ for $4 \mathrm{~h}$ (maximum time of travel to the lab), after which the FA extraction was performed immediately.

At the end of the experimental period, the lambs were transported to a private abattoir (Ronse, Belgium) without prior fastening and slaughtered according to conventional practice. Ruminal ( $1 \mathrm{I}$ ) and abomasal $(0.5 \mathrm{I})$ contents were sampled into plastic pots after thorough mixing, and kept refrigerated until arrival in the lab. To ensure correct sampling, the $\mathrm{pH}$ of both stomach contents was measured at three different locations in each stomach. Rumen samples were prepared for volatile fatty acid (VFA) analysis, as soon as they arrived in the lab. The sample residues were freeze-dried and kept at ambient temperature (1 month) until analysis of FA. Samples for VFA analysis were acidified with phosphoric/formic acid (10/1 vol/vol) and centrifuged for $15 \mathrm{~min}$ at $31000 \mathrm{~g}$. The supernatant was recovered and $1 \mathrm{ml}$ was transferred to vials and analysed by gas chromatography (Schimadzu GC-14A, Belgium), according to Van Nevel and Demeyer (1977).

Meat and subcutaneous fat samples were taken $24 \mathrm{~h}$ after slaughter, from chilled carcasses $\left(4^{\circ} \mathrm{C}\right)$. Meat samples were taken from the $m$. longissimus thoracis, from the left side of the carcass (between T7 and T8). Meat and subcutaneous fat samples were stored vacuum packed at $-20^{\circ} \mathrm{C}$ until FA analysis.

\section{Chemical composition analysis}

Samples for chemical composition determination were dried at $50^{\circ} \mathrm{C}$ for $48 \mathrm{~h}$, finely ground $(0.5$ to $1 \mathrm{~mm}$ ) (Grindomix GM 200, Retsch, Germany) and further analysed. Chemical composition analysis consisted of determination of crude protein, according to the Kjedahl method (European Community, 1993), neutral-detergent fibre (NDF) and acid-detergent fibre (ADF) using the Van Soest method (Van Soest et al., 1991), lignin according to the method described by Van Soest and Wine (1968) and crude fat with the Soxhlet method (International Standards Organisation, ISO-1444, 1973). Results are presented in Table 2.

\section{Fatty acid analysis}

Extraction. FA of fresh grass samples (from the three different pastures) were extracted in triplicate with chloroform/methanol (2/1, vol/vol) (C/M), as described by Lourenço and Fievez (2005). Briefly, $5 \mathrm{~g}$ of fresh material was cut into $1-\mathrm{cm}$ strips and homogenised for $1 \mathrm{~min}$ at 900 r.p.m. (Ultra-Turrax T25, IKA-Labortechnik, Belgium). The endogenous water was determined $\left(105^{\circ} \mathrm{C}\right.$ for $\left.4 \mathrm{~h}\right)$ in order to adjust the ratio of chloroform/methanol/water to $8 / 4 / 3$ ( $\mathrm{vol} / \mathrm{vol} / \mathrm{vol})$. In all samples, $40 \mathrm{ml}$ of C/M (2/1, $\mathrm{vol} / \mathrm{vol}$ ) and $10 \mathrm{mg}$ of nonadecanoic acid (C19:0; Sigma, Belgium) as internal standard were added and samples
Table 2 Chemical composition of the three pastures, expressed as g/kg dry matter $(n=3)$

\begin{tabular}{lccccc}
\hline \hline & \multicolumn{5}{c}{ Pasture } \\
\cline { 2 - 6 } & BD & $\mathrm{L}$ & $\mathrm{IR}$ & s.e. & Significance \\
\hline Dry matter $(\mathrm{g} / \mathrm{kg})$ & $932^{\mathrm{a}}$ & $926^{\mathrm{b}}$ & $933^{\mathrm{a}}$ & 0.154 & $*$ \\
Crude protein & $98.8^{\mathrm{b}}$ & $235^{\mathrm{a}}$ & $148^{\mathrm{b}}$ & 2.23 & $* *$ \\
Fat & 36.0 & 37.3 & $37.2^{\dagger}$ & 0.504 & n.s. \\
Acid-detergent fibre & 342 & 293 & 327 & 2.63 & n.s. \\
Neutral-detergent & $571^{\mathrm{a}}$ & $396^{\mathrm{b}}$ & $567^{\mathrm{a}}$ & 3.60 & $*$ \\
$\quad$ fibre (NDF) & & & & & \\
Ash in NDF & 37.6 & 27.6 & 24.8 & 0.332 & n.s. \\
Lignin & 54.0 & 70.7 & 43.7 & 0.938 & n.s. \\
\hline \hline
\end{tabular}

a,b,c Means with different superscripts in the same row differ significantly $(P<0.05)$. n.s. $=$ not significantly different $(P>0.05)$.

${ }^{+} n=2$.

were extracted overnight. The next morning, samples were centrifuged at $1821 \mathrm{~g}$ for $10 \mathrm{~min}$ and the $\mathrm{C} / \mathrm{M}$ layer was recovered. In a second and third extraction step, $30 \mathrm{ml}$ and $20 \mathrm{ml}$ of $\mathrm{C} / \mathrm{M}(2 / 1$, vol/vol) respectively, were added and the samples were centrifuged at $1821 \mathrm{~g}$ for $10 \mathrm{~min}$ for every extraction step. The extracts were combined and washed once with distilled water and the C/M layer was recovered. Finally, the extracts were brought to a final volume of $100 \mathrm{ml}$ with $\mathrm{C} / \mathrm{M}(2 / 1, \mathrm{vol} / \mathrm{vol})$.

Rumen and abomasum samples were analysed in duplicate for FA as described for rumen samples by Lourenço et al. (2005). Briefly $2.5 \mathrm{~g}$ of freeze-dried sample was extracted overnight with $30 \mathrm{ml}$ of C/M (2/1, vol/vol), $20 \mathrm{ml}$ of distilled water and $10 \mathrm{mg}$ of nonadecanoic acid (C19:0; Sigma, Belgium) as internal standard. Samples were then centrifuged at $1821 \mathrm{~g}$ for $10 \mathrm{~min}$ and the C/M layer was recovered. This procedure was repeated twice, adding $25 \mathrm{ml}$ of C/M (2/1, $\mathrm{vol} / \mathrm{vol}$ ) in the second and $20 \mathrm{ml}$ in the third extraction step. Finally, samples were washed with distilled water and the $\mathrm{C} / \mathrm{M}$ layer was recovered. Extracts were brought to a final volume of $100 \mathrm{ml}$ with C/M (2/1, vol/vol).

Meat samples were extracted in duplicate as described by Raes et al. (2001). Briefly, $5 \mathrm{~g}$ of meat was homogenised for $30 \mathrm{~s}$ at 9000 r.p.m. (Ultra-Turrax T25, IKA-Labortechnik, Belgium) and extracted overnight with $30 \mathrm{ml}$ of $\mathrm{C} / \mathrm{M}(2 / 1, \mathrm{vol} / \mathrm{vol})$ and $3 \mathrm{~mL}$ of BHT in chloroform $(0.1 \%, \mathrm{w} /$ vol). Samples were then filtered (Fiorini, S.A.) and the filtrate was collected. The filter was washed twice with $10 \mathrm{ml}$ of C/M (2/1, vol/vol). The filtrate was transferred to the extraction tubes and $15 \mathrm{ml}$ of distilled water was added. Samples were centrifuged at $1821 \mathrm{~g}$ for $10 \mathrm{~min}$ and the C/M layer was recovered and evaporated with a rotavapor (Laborota $4000 \mathrm{WB}$, Germany) at $40^{\circ} \mathrm{C}$. The dry residue was then re-suspended in $10 \mathrm{ml}$ of $\mathrm{C} / \mathrm{M}(2 / 1$, vol/vol).

Subcutaneous fat samples $(1 \mathrm{~g})$ were extracted using a similar procedure as described before for FA extraction of meat (Raes et al., 2001), however the bottom layer was recovered into volumetric flasks after washing with distilled water and was brought to a final volume of $100 \mathrm{ml}$ with Cl $\mathrm{M}(2 / 1, \mathrm{vol} / \mathrm{vol})$. 
Methylation. For methylation of intramuscular and subcutaneous FA, $2 \mathrm{ml}$ of extract was taken and $1 \mathrm{ml}$ of nonadecanoic acid (2 mg/ml; C19:0; Sigma, Belgium) was added. For methylation of grass, rumen or abomasum FA, $10 \mathrm{ml}$ of extract was used. Samples were methylated at $50^{\circ} \mathrm{C}$ with $\mathrm{NaOH}$ in methanol $(0.5 \mathrm{~mol} / \mathrm{l})$ followed by $\mathrm{HCl} /$ methanol (1/1, vol/vol) according to Raes et al. (2001).

Gas chromatography. Fatty acids methyl esters (FAME) were analysed on a Hewlett-Packard 6890 gas chromatograph (Hewlett-Packard Co., Belgium) with a CPSil88 column for FAME $(100 \mathrm{~m} \times 0.25 \mathrm{~mm} \times 0.2 \mu \mathrm{m}$; Chrompack Inc., The Netherlands). For more detailed information about the GC analysis of rumen, abomasum, intramuscular and subcutaneous fat samples we refer to Raes et al. (2004). For the grass FA the following temperature program was used: $150^{\circ} \mathrm{C}$ for $2 \mathrm{~min}$, followed by an increase at a rate of $1^{\circ} \mathrm{C} / \mathrm{min}$ until $200^{\circ} \mathrm{C}$. Temperature of the injector and detector was $250^{\circ} \mathrm{C}$ and $280^{\circ} \mathrm{C}$, respectively. Separation of the isomers C18:1 t10 and C18:1 t11 was not possible due to the status of the GC column. CLA cis-cis (CLA CC) isomers and CLA transtrans (CLA tt) isomers are reported as the sum of all CLA isomers with two cis and trans double bounds, respectively, as with the GC method used it is not possible to have a clear separation of these isomers.

\section{Statistics}

A one-way ANOVA was used to evaluate the effect of the different pastures on grass, rumen, abomasum, intramucular and subcutaneous fat FA and rumen VFA, according to $Y_{i}=\mu B_{i}+\varepsilon_{i}$, where $\mu$ is the overall mean, $B_{i}$ the effect of the different pastures and $\varepsilon_{i}$ the residual error. Comparison of means was done using Duncan as post-hoc test.

Principal component analysis (PCA), based on the correlation matrix, was conducted to determine components which account for most of the total variation in odd- and branched-chain fatty acids (OBCFA). Each object (animal $x$ treatment, $\mathrm{n}=21$ ) was considered to be a data vector of 11 variables (iso C13:0, anteiso C13:0, C13:0, iso C14:0,

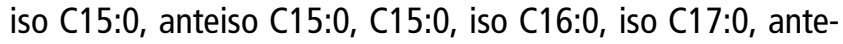
iso $\mathrm{C} 17: 0$ and $\mathrm{C} 17: 0$ all expressed as \% of total OBCFA). The principal component scores are presented in a scatter plot to evaluate grouping of treatments. Statistical analyses were performed using SPSS (SPSS software for Windows, release 11.0, SPSS Inc., USA).

\section{Results}

Live-weight gain of the animals grazing pasture BD was very low and significantly lower than for animals grazing pastures L or IR. Average live weight at slaughter was 24.8 (s.d. 4.2) $\mathrm{kg}$ for the pasture BD group compared with 35.6 (3.8) and 36.4 (3.5) $\mathrm{kg}$ for the L and IR group respectively.
Chemical composition and fatty acid composition of the pastures

As shown in Table 2, protein content was lowest and NDF content was highest for BD pasture. Unexpectedly, NDF content of pasture IR was similar to the NDF content of pasture BD.

FA composition of the pastures is presented in Table 3. It is clear that pasture $L$ had the highest total FA content $(29.8 \mathrm{mg} / \mathrm{g} \mathrm{DM})$. Nevertheless, the proportions of PUFA (C18:3 n-3 + C18:2 n-6) were rather similar between groups, with the IR pasture being richer in C18:3 n-3 and the BD pasture having a higher proportion of C18:2 n-6.

Fatty acid composition of rumen and abomasum contents Total rumen concentrations of VFA, proportions of individual VFA ( $\mathrm{mmol} / \mathrm{mol}$ total VFA) and some ratios are presented in Table 4. Fermentation patterns were as expected showing the highest acetate and lowest propionate proportions for the animals grazing BD pasture. Pasture $\mathrm{L}$ induced lower acetate and higher valerate and butyrate proportions.

Total long-chain FA content and proportions of rumen contents are presented in Table 5. For rumen and abomasum contents, the proportions of C18-FA are also expressed relative to the sum of all C18-FA, as this allows a better evaluation of rumen hydrogenation when dietary supply of C18-FA differs (Chow et al., 2004). Rumen contents of $\mathrm{BD}$ pasture animals clearly had the lowest amount of total FA, reflecting the lower total FA content of the pasture samples. Proportions of $\mathrm{C} 18: 3 \mathrm{n}-3$ in rumen contents were very similar among treatments, whereas proportions of C18:2 n-6 were significantly higher in the rumen of animals grazing the $L$ pasture compared with the IR pasture animals, with the BD pasture group being intermediate.

Table 3 Total fatty acid (FA) content ( $\mathrm{mg} / \mathrm{g}$ dry matter) and proportions of $F A\left(g / 100 \mathrm{~g}\right.$ of $\left.\mathrm{FAME}^{+}\right)$of the grass samples taken during the 12 weeks of the experimental period, of the three different pastures $(n=12)$

\begin{tabular}{|c|c|c|c|c|c|}
\hline & \multicolumn{5}{|c|}{ Pasture } \\
\hline & $\mathrm{BD}$ & $\mathrm{L}$ & IR & s.e. & Significance \\
\hline Dry matter $(\mathrm{g} / 100 \mathrm{~g})$ & $25.5^{\mathrm{a}}$ & $17.1^{b}$ & $18.6^{\mathrm{b}}$ & 0.014 & $* * *$ \\
\hline Total fatty acids & $18.5^{c}$ & $29.8^{a}$ & $25.5^{\mathrm{b}}$ & 1.23 & $* * *$ \\
\hline C12:0 & $0.622^{\mathrm{a}}$ & $0.404^{b}$ & $0.599^{a}$ & 0.044 & $* *$ \\
\hline $\mathrm{C} 14: 0$ & 1.82 & 2.06 & 2.04 & 0.147 & n.s. \\
\hline C16:0 & 14.5 & 15.1 & 14.4 & 0.403 & n.s. \\
\hline C16:1 c9 & $1.73^{b}$ & $2.14^{\mathrm{a}}$ & $1.79^{b}$ & 0.081 & $* *$ \\
\hline C18:0 & 3.00 & 3.50 & 2.78 & 0.418 & n.s. \\
\hline C18:1 c9 & $3.83^{a}$ & $2.61^{b}$ & $2.88^{\mathrm{b}}$ & 0.248 & $* *$ \\
\hline C18:2 n-6 & $18.2^{\mathrm{a}}$ & $17.3^{\mathrm{a}}$ & $13.9^{b}$ & 0.778 & $* *$ \\
\hline C18:3 n-3 & $51.7^{b}$ & $52.1^{b}$ & $57.2^{\mathrm{a}}$ & 1.67 & * \\
\hline Total C18 & 76.8 & 76.7 & 75.5 & 0.638 & n.s. \\
\hline
\end{tabular}


Table 4 Total volatile fatty acid content (VFA, mol/l) and relative proportions of individual VFA) ( $\mathrm{mmol} / \mathrm{mol}$ total VFA) in the rumen of the animals grazing three different pastures $(n=7)$

\begin{tabular}{lccccc}
\hline \hline & \multicolumn{5}{c}{ Pasture } \\
\cline { 2 - 7 } & \multicolumn{6}{c}{ BD } & $\mathrm{L}$ & IR & s.e. & Significance \\
\hline Total & $0.108^{\mathrm{b}}$ & $0.156^{\mathrm{a}}$ & $0.109^{\mathrm{b}}$ & 0.006 & $* * *$ \\
Acetate & $672^{\mathrm{a}}$ & $598^{\mathrm{c}}$ & $636^{\mathrm{b}}$ & 6.05 & $* * *$ \\
Propionate & $174^{\mathrm{b}}$ & $197^{\mathrm{a}}$ & $197^{\mathrm{a}}$ & 6.69 & $*$ \\
Butyrate & $114^{\mathrm{c}}$ & $146^{\mathrm{a}}$ & $130^{\mathrm{b}}$ & 4.08 & $* * *$ \\
Valerate & $12.8^{\mathrm{b}}$ & $18.2^{\mathrm{a}}$ & $13.6^{\mathrm{b}}$ & 0.484 & $* * *$ \\
Ratios & & & & & \\
$\quad$ Ac/Prop & $3.25^{\mathrm{b}}$ & $3.09^{\mathrm{b}}$ & $3.91^{\mathrm{a}}$ & 0.142 & $* *$ \\
$\quad$ (Ac + But)/Prop & $3.91^{\mathrm{b}}$ & $3.84^{\mathrm{b}}$ & $4.57^{\mathrm{a}}$ & 0.175 & $*$ \\
\hline \hline
\end{tabular}

$a, b, c$ Means in same row with different superscripts differ significantly $(P<0.05)$.

${ }^{+}$Ac: acetate; But: butyrate; Prop: propionate.

Rumen contents of animals grazing the BD pasture contained higher proportions of intermediates (C18:1 $\mathrm{t} 10+\mathrm{t} 11 ; \mathrm{C} 18: 2 \mathrm{t} 11 \mathrm{c} 15$ and CLA c9t11) of the major rumen biohydrogenation pathways of $\mathrm{C} 18: 2 \mathrm{n}-6$ and $\mathrm{C} 18: 3$ n-3 (8.27\% of FAME vs. 5.59 and $5.15 \%$ of FAME for the $B D$ v. $L$ and IR pastures, respectively). This is particularly true for the isomers $\mathrm{C} 18: 1 \mathrm{t} 10+\mathrm{t} 11$ and for the CLA isomer c9t11, whereas other intermediates (e.g. C18:3 c9t11 c15) of the major biohydrogenation pathway of C18:3 $\mathrm{n}-3$ were reduced. When expressed as proportion of total C18-FA, the difference between the three treatments becomes even more obvious (Table 5). Some intermediates of secondary biohydrogenation pathways (e.g. C18:1 t9, CLA t10c12) were also higher in the rumen contents of $B D$ pasture animals, whereas end and intermediate products of other pathways (e.g. C18:1 c15) were significantly reduced.

Compared with the rumen, the abomasum contents were richer in total amount of FA and in saturated fat (Table 6), which is not surprising considering the absorption from the rumen of fermentation end products of carbohydrates and proteins, and the biohydrogenation of unsaturated $F A$, respectively. IR and $L$ pastures induced higher amounts of total FA but animals of pastures $B D$ and $L$ had lower amounts of C18:0, as for rumen samples. However, the proportion of biohydrogenation intermediates (C18:1 t10 + t11, C18:1 C15, CLAc9t11, C18:2 t11 c15 and C18:3 $c 9 t 11 \mathrm{c} 15)$ was lower than in the rumen for all three groups (5.52, 5.20 and $5.32 \%$ of FAME for animals of pasture $B D, L$ and $I R$, respectively). Most of the differences found between the groups in the rumen samples were no longer apparent in the abomasum samples.

Similarly to what was observed in the rumen contents, proportions of C18:2 n- 6 in the abomasum contents were significantly higher for the $L$ pasture lambs than for the IR pasture lambs. Moreover, compared with both other groups, abomasal contents of $L$ pasture lambs was significantly enriched in C18:3 n-3, although this difference has not been observed in the rumen.
Table 5 Total medium- and long-chain fatty acid content (mg/g DM) and fatty acid composition (g/100 g FAME) of rumen contents of the animals grazing three different pastures $(n=7)$

\begin{tabular}{|c|c|c|c|c|c|}
\hline & \multicolumn{5}{|c|}{ Pasture } \\
\hline & $\mathrm{BD}$ & L & IR & s.e. & Significance \\
\hline \multicolumn{6}{|l|}{ Fatty acids ${ }^{\dagger}$} \\
\hline Total & $45.2^{c}$ & $55.4^{\mathrm{b}}$ & $63.6^{a}$ & 1.56 & $* * *$ \\
\hline $\mathrm{C} 12: 0$ & $0.293^{a}$ & $0.210^{b}$ & $0.218^{b}$ & 0.012 & $* * *$ \\
\hline $\mathrm{C} 14: 0$ & $0.741^{\mathrm{a}}$ & $0.618^{b}$ & $0.812^{\mathrm{a}}$ & 0.039 & ** \\
\hline C16:0 & 13.1 & 13.4 & 14.1 & 0.302 & $\neq$ \\
\hline C18:0 & $53.1^{\mathrm{b}}$ & $55.4^{\mathrm{ab}}$ & $57.6^{a}$ & 0.787 & ** \\
\hline C18:1 t9 & $0.470^{\mathrm{a}}$ & $0.339^{b}$ & $0.236^{c}$ & 0.031 & $* * *$ \\
\hline $\mathrm{C} 18: 1 \mathrm{t} 10+\mathrm{t} 11$ & $7.29^{\mathrm{a}}$ & $4.72^{\mathrm{b}}$ & $4.47^{b}$ & 0.365 & $* * *$ \\
\hline C18:1 c9 & $3.51^{\mathrm{b}}$ & $4.69^{a}$ & $3.89^{b}$ & 0.238 & $* *$ \\
\hline C18:1 c15 & $0.185^{b}$ & $0.456^{\mathrm{a}}$ & $0.406^{\mathrm{a}}$ & 0.043 & ** \\
\hline CLA c9t11 & $0.113^{\mathrm{a}}$ & $0.068^{b}$ & $0.057^{b}$ & 0.010 & ** \\
\hline CLA t10c12 & $0.172^{\mathrm{a}}$ & $0.077^{c}$ & $0.125^{b}$ & 0.012 & $* * *$ \\
\hline CLAtt & 0.084 & 0.094 & 0.084 & 0.009 & n.s. \\
\hline C18:2 t11c15 & 0.867 & 0.803 & 0.625 & 0.069 & $\neq$ \\
\hline C18:3 c9t11c15 & $0.237^{b}$ & $0.371^{\mathrm{a}}$ & $0.266^{\mathrm{b}}$ & 0.027 & ** \\
\hline C18:2 n-6 & $1.53^{\mathrm{ab}}$ & $1.78^{\mathrm{a}}$ & $1.27^{\mathrm{b}}$ & 0.109 & * \\
\hline C18:3 n-3 & 1.79 & 1.77 & 1.87 & 0.098 & n.s. \\
\hline Total C18 & $72.6^{\mathrm{b}}$ & $75.1^{\mathrm{a}}$ & $74.5^{\mathrm{a}}$ & 0.311 & $* * *$ \\
\hline Total OLCFA & $3.07^{\mathrm{a}}$ & $2.65^{b}$ & $2.39^{c}$ & 0.072 & $* * *$ \\
\hline Total BCFA & $4.08^{a}$ & $3.29^{b}$ & $3.04^{b}$ & 0.100 & $* * *$ \\
\hline Total MUFA & $16.5^{\mathrm{a}}$ & $16.1^{\mathrm{a}}$ & $14.1^{\mathrm{b}}$ & 0.661 & * \\
\hline \multicolumn{6}{|c|}{ C18 fatty acids as $\%$ of total $\mathrm{C} 18$} \\
\hline C18:0 & $73.2^{\mathrm{b}}$ & $73.8^{\mathrm{b}}$ & $77.3^{\mathrm{a}}$ & 1.03 & * \\
\hline C18:1t9 & $0.648^{\mathrm{a}}$ & $0.452^{\mathrm{b}}$ & $0.316^{c}$ & 0.043 & $* * *$ \\
\hline $\mathrm{C} 18: 1 \mathrm{t} 10+\mathrm{t} 11$ & $10.0^{\mathrm{a}}$ & $6.28^{b}$ & $6.00^{\mathrm{b}}$ & 0.473 & $* * *$ \\
\hline C18:1 c9 & $4.84^{\mathrm{b}}$ & $6.24^{\mathrm{a}}$ & $5.23^{b}$ & 0.323 & $* *$ \\
\hline C18:1 c15 & $0.255^{\mathrm{b}}$ & $0.606^{\mathrm{a}}$ & $0.545^{\mathrm{a}}$ & 0.056 & ** \\
\hline CLA c9t11 & $0.156^{\mathrm{a}}$ & $0.094^{b}$ & $0.079^{b}$ & 0.013 & ** \\
\hline CLA t10c12 & $0.238^{\mathrm{a}}$ & $0.106^{c}$ & $0.172^{b}$ & 0.017 & $* * *$ \\
\hline CLAtt & 0.115 & 0.130 & 0.128 & 0.013 & n.s. \\
\hline C18:2 t11c15 & $1.20^{\mathrm{a}}$ & $1.07^{\mathrm{ab}}$ & $0.839^{b}$ & 0.096 & * \\
\hline C18:3 c9t11c15 & $0.326^{b}$ & $0.494^{\mathrm{a}}$ & $0.358^{b}$ & 0.036 & * \\
\hline C18:2 n-6 & $2.11^{\mathrm{ab}}$ & $2.38^{\mathrm{a}}$ & $1.70^{\mathrm{b}}$ & 0.151 & * \\
\hline C18:3 n-3 & 2.47 & 2.49 & 2.37 & 0.136 & n.s. \\
\hline
\end{tabular}

a,b,c Means with different superscripts in the same row differ significantly $(P<0.05)$. n.s. not significantly different $(P>0.05)$.

${ }^{\dagger}$ Fatty acids abbreviation codes are as follows. Total OLCFA: sum of odd linear chain fatty acids: C13:0, C15:0, C17:0 and C17:1. Total BCFA: sum of branched chain fatty acids: iso $\mathrm{C} 12: 0$, anteiso $\mathrm{C12:0}$, iso $\mathrm{C13:0}$, anteiso $\mathrm{C} 13: 0$, iso $\mathrm{C} 14: 0$, anteiso $\mathrm{C} 14: 0$, iso $\mathrm{C} 15: 0$, anteiso $\mathrm{C} 15: 0$, iso $\mathrm{C} 16: 0$, anteiso C16:0, iso C17:0 and anteiso C17:0. Total MUFA: sum of monounsaturated fatty acids: C14:1 c9, C15:1, C16:1 t, C16:1 c9, C18:1 t6-t8, C18:1 t9, C18:1 $\mathrm{t} 10+\mathrm{t} 11, \mathrm{C} 18: 1 \mathrm{t} 12-\mathrm{t} 14, \mathrm{C} 18: 1 \mathrm{c} 9, \mathrm{C} 18: 1 \mathrm{c11}, \mathrm{C18:1} \mathrm{c12}, \mathrm{C} 18: 1$ c13, C18:1 $\mathrm{c} 14+\mathrm{t} 16$ and C18:1 c15. FAME: fatty acids methyl esters.

${ }^{\ddagger}$ Approaching significance $(P<0.1)$.

Rumen biohydrogenation intermediates as well as changes in rumen OBCFA can give an indication for changes in the rumen microbial population. Thus, OBCFA were used in a biplot analysis (Figure 1), to determine the components which account for most of the variation in OBCFA. The separation of the different dietary groups was mainly based on the first component, with a positive higher score for the $\mathrm{BD}$ pasture animals and a more negative score for the IR pasture animals. C14:0 iso was more 
Lourenço, Van Ranst, De Smet, Raes and Fievez

Table 6 Total fatty acid content ( $\mathrm{mg} / \mathrm{g}$ dry matter) and fatty acid composition (g/100 $\mathrm{g}$ of FAME) of abomasum contents of the animals grazing the three different pastures $(n=7)$

\begin{tabular}{|c|c|c|c|c|c|}
\hline & \multicolumn{5}{|c|}{ Pasture } \\
\hline & $\mathrm{BD}$ & L & IR & s.e. & Significanc \\
\hline \multicolumn{6}{|l|}{ Fatty acids ${ }^{\dagger}$} \\
\hline Total & $52.4^{b}$ & $76.0^{\mathrm{a}}$ & $84.1^{\mathrm{a}}$ & 3.10 & $* * *$ \\
\hline C12:0 & $0.244^{\mathrm{a}}$ & $0.138^{b}$ & $0.100^{b}$ & 0.015 & $* * *$ \\
\hline C14:0 & $0.588^{a}$ & $0.436^{\mathrm{b}}$ & $0.556^{\mathrm{a}}$ & 0.022 & $* * *$ \\
\hline C16:0 & $11.9^{b}$ & $11.5^{\mathrm{b}}$ & $12.6^{\mathrm{a}}$ & 0.243 & * \\
\hline C18.0 & $59.4^{b}$ & $60.6^{\mathrm{b}}$ & $63.8^{a}$ & 0.893 & ** \\
\hline C18:1 t9 & 0.444 & 0.498 & 0.448 & 0.040 & n.s. \\
\hline $\mathrm{C} 18: 1 \mathrm{t} 10+\mathrm{t} 11$ & 4.40 & 3.58 & 4.14 & 0.411 & n.s. \\
\hline C18:1 c9 & $4.76^{\mathrm{a}}$ & $4.89^{a}$ & $3.47^{\mathrm{b}}$ & 0.313 & $* *$ \\
\hline C18:1 c15 & $0.522^{b}$ & $0.831^{\mathrm{a}}$ & $0.564^{\mathrm{b}}$ & 0.052 & ** \\
\hline CLA c9t11 & 0.058 & 0.019 & 0.007 & 0.018 & n.s. \\
\hline CLA t10c12 & $0.105^{a}$ & $0.049^{b}$ & $0.091^{\mathrm{ab}}$ & 0.014 & $*$ \\
\hline CLA tt & $0.078^{b}$ & $0.145^{\mathrm{a}}$ & $0.109^{a b}$ & 0.017 & * \\
\hline C18:2 t11c15 & 0.335 & 0.417 & 0.391 & 0.035 & n.s. \\
\hline C18:3 c9t11c15 & $0.200^{b}$ & $0.350^{\mathrm{a}}$ & $0.219^{b}$ & 0.028 & $* *$ \\
\hline C18:2 n-6 & $1.54^{\mathrm{a}}$ & $1.87^{\mathrm{a}}$ & $0.872^{\mathrm{b}}$ & 0.114 & $* * *$ \\
\hline C18:3 n-3 & $1.59^{b}$ & $2.00^{\mathrm{a}}$ & $1.24^{\mathrm{b}}$ & 0.133 & $* *$ \\
\hline Total C18 & $77.6^{c}$ & $80.1^{a}$ & $78.7^{\mathrm{b}}$ & 0.355 & $* * *$ \\
\hline Total OLCFA & $2.01^{\mathrm{a}}$ & $1.59^{c}$ & $1.84^{b}$ & 0.053 & $* * *$ \\
\hline Total BCFA & $2.56^{\mathrm{a}}$ & $2.23^{b}$ & $1.89^{c}$ & 0.062 & $* * *$ \\
\hline Total MUFA & $15.6^{\mathrm{a}}$ & $15.7^{\mathrm{a}}$ & $12.9^{b}$ & 0.829 & * \\
\hline \multicolumn{6}{|c|}{ C18 fatty acids as $\%$ of total C18 } \\
\hline $\mathrm{C} 18: 0$ & $76.5^{\mathrm{b}}$ & $75.7^{\mathrm{b}}$ & $81.3^{\mathrm{a}}$ & 1.12 & ** \\
\hline C18:1t9 & 0.573 & 0.622 & 0.568 & 0.048 & n.s. \\
\hline $\mathrm{C} 18: 1 \mathrm{t} 10+\mathrm{t} 11$ & 5.66 & 5.19 & 4.46 & 0.503 & n.s. \\
\hline C18:1 c9 & $6.14^{\mathrm{a}}$ & $6.10^{\mathrm{a}}$ & $4.45^{b}$ & 0.368 & ** \\
\hline C18:1 c15 & $0.673^{b}$ & $1.04^{\mathrm{a}}$ & $0.700^{\mathrm{b}}$ & 0.062 & ** \\
\hline CLA c9t11 & 0.075 & 0.024 & 0.071 & 0.043 & n.s. \\
\hline CLA t10c12 & $0.136^{\mathrm{a}}$ & $0.061^{b}$ & $0.116^{\mathrm{a}}$ & 0.018 & * \\
\hline CLAtt & $0.100^{b}$ & $0.181^{\mathrm{a}}$ & $0.136^{\mathrm{ab}}$ & 0.021 & * \\
\hline $\mathrm{C} 18: 2 \mathrm{t} 11 \mathrm{c} 15$ & 0.431 & 0.521 & 0.478 & 0.042 & n.s. \\
\hline C18:3 c9t11c15 & $0.259^{b}$ & $0.437^{a}$ & $0.291^{\mathrm{b}}$ & 0.035 & $* *$ \\
\hline C18:2 n-6 & $1.98^{\mathrm{a}}$ & $2.33^{\mathrm{a}}$ & $1.05^{b}$ & 0.144 & $* * *$ \\
\hline C18:3 n-3 & $2.06^{\mathrm{a}}$ & $2.50^{\mathrm{a}}$ & $1.49^{b}$ & 0.168 & ** \\
\hline
\end{tabular}

a,b,c Means with different superscripts in the same row differ significantly $(P<0.05)$. n.s. not significantly different $(P>0.05)$.

${ }^{\dagger}$ Fatty acids abbreviation codes are as follows. Total OLCFA: sum of odd linear-chain fatty acids: C13:0, C15:0, C17:0 and C17:1. Total BCFA: sum of branched-chain fatty acids: iso $\mathrm{C12:0}$, anteiso $\mathrm{C12:0}$, iso $\mathrm{C13:0}$, anteiso $\mathrm{C} 13: 0$, iso $\mathrm{C} 14: 0$, anteiso $\mathrm{C} 14: 0$, iso $\mathrm{C} 15: 0$, anteiso $\mathrm{C} 15: 0$, iso $\mathrm{C} 16: 0$, anteiso C16:0, iso C17:0 and anteiso C17:0. Total MUFA: sum of monounsaturated fatty acids: C14:1 c9, C15:1, C16:1 t, C16:1 c9, C18:1 t6-t8, C18:1 t9, C18:1 $\mathrm{t} 10+\mathrm{t} 11, \mathrm{C} 18: 1 \mathrm{t} 12-\mathrm{t} 14, \mathrm{C} 18: 1 \mathrm{c} 9, \mathrm{C} 18: 1 \mathrm{c11}, \mathrm{C18}: 1 \mathrm{c12}, \mathrm{C} 18: 1 \mathrm{c13}, \mathrm{C18:1}$ $\mathrm{c} 14+\mathrm{t} 16$ and C18:1 c15. FAME: fatty acids methyl esters.

negatively correlated with the first component as well as C17:0 and C15:0 anteiso, whereas C13:0 iso, C15:0 iso and $\mathrm{C} 15: 0$ were strongly positive correlated with the first component.

\section{Subcutaneous and intramuscular fatty acid composition}

The FA content of subcutaneous fat was relatively low and its pattern was mainly a reflection of what was found in the abomasum (Table 7), although some differences

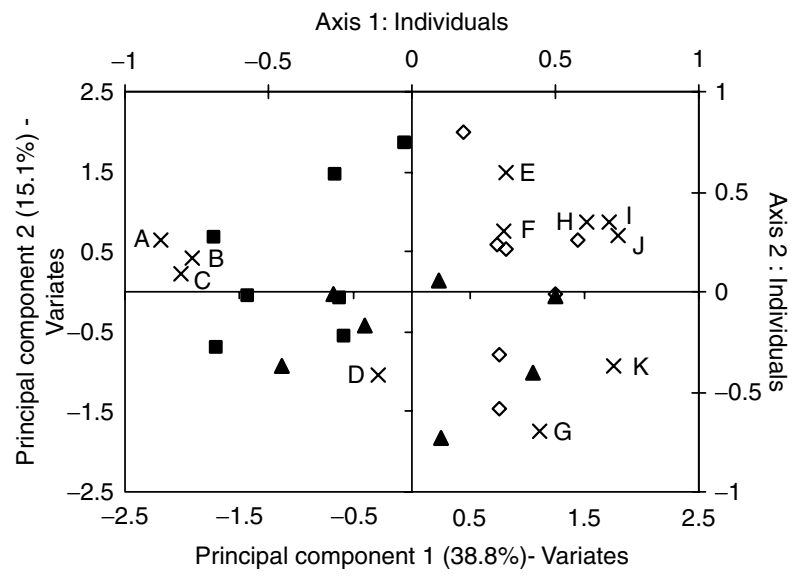

Figure 1 Biplot representing both regression factor scores according to the pasture groups (Botanical diverse $(\diamond)$, Intensive ryegrass $(\boldsymbol{\square})$, Leguminosa rich $(\mathbf{\Lambda}))$ and loadings $(\mathrm{x})$ of the first two principal components, based on proportions ( $\%$ of total OBCFA) of rumen OBCFA. The letters refer to individual OBCFA: A - C14:0 iso; $\mathrm{B}$ - C17:0; C - C15:0 anteiso; D - C17:0 anteiso; E - C13:0 anteiso; F - C17:0 iso; G C13:0; H - C16:0 iso; I - C15:0 iso; J - C13:0 iso; $\mathrm{K}$ - C15:0.

between groups were no longer significant (e.g. C18:0). Higher proportions for $\mathrm{C} 18: 3 \mathrm{n}-3$ and $\mathrm{C} 18: 2 \mathrm{n}-6$ were found in the subcutaneous fat of the animals grazing the $L$ pasture, which is consistent with the abomasum data. The proportion of CLA c9t11 in the subcutaneous fat was significantly higher for animals grazing BD pasture compared with the other pasture groups. Concerning other CLA isomers, BD pasture animals presented the lowest CLA CC and a trend for higher CLA $\mathrm{t} 10 \mathrm{C} 12$ and lower CLA tt proportions.

Total content of FA in the intramuscular fat did not differ between groups (Table 8). However, significantly higher proportions of C18:3 n-3 were found in the intramuscular fat of the animals grazing the $L$ pasture, being consistent with abomasum and subcutaneous fat data. On the other hand, proportions of C18:2 n- 6 were significantly higher in the intramuscular fat of $B D$ pasture animals. Neither intramuscular fat proportions of CLA c9t11, nor CLA t10c12 differed between the three treatments. CLA tt proportions were significantly higher and CLA cc proportions tended to be higher in intramuscular fat of $L$ pasture animals. Proportions of C18:1 c9 were significantly higher for animals of $L$ and IR pastures compared with the BD pasture animals. Concerning FA of longer chain length, significantly higher proportions of $\mathrm{C} 20: 4 \mathrm{n}-6, \mathrm{C} 20: 5 \mathrm{n}-3$ and C22:5 n-3 were present in the muscle of $B D$ pasture animals, but no significant difference was found for $\mathrm{C} 22: 6 \mathrm{n}-3$. On the other hand, the content of these long-chain FA (LCFA - FA with 20 or more $C$ atoms) did not differ between groups (data not shown), except for C20:4 n-6 remaining significantly higher for the BD pasture lambs. Most indices of elongation and desaturation activity, as calculated by ratios of product to precursor $F A$, were significantly higher in muscle of BD grazing animals (Table 8). 
Table 7 Total fatty acid content (mg/g fat) and fatty acid composition ( $g / 100 \mathrm{~g}$ of FAME) of subcutaneous fat of the animals grazing the three different pastures $(n=7)$

\begin{tabular}{|c|c|c|c|c|c|}
\hline & \multicolumn{5}{|c|}{ Pasture } \\
\hline & $\mathrm{BD}$ & L & IR & s.e. & Significance \\
\hline \multicolumn{6}{|l|}{ Fatty acids $^{\dagger}$} \\
\hline Total & 609 & 669 & 660 & 18.8 & $\neq$ \\
\hline C12:0 & $0.644^{a}$ & $0.131^{b}$ & $0.225^{b}$ & 0.065 & $* * *$ \\
\hline $\mathrm{C} 14: 0$ & $5.98^{\mathrm{a}}$ & $2.40^{\mathrm{b}}$ & $2.96^{\mathrm{b}}$ & 0.445 & $* * *$ \\
\hline C16:0 & 20.5 & 19.8 & 18.2 & 0.668 & $\neq$ \\
\hline C18:0 & 25.7 & 25.1 & 29.1 & 1.95 & n.s. \\
\hline C18:1 t9 & $0.667^{b}$ & $0.802^{a}$ & $0.441^{\mathrm{c}}$ & 0.040 & $* * *$ \\
\hline $\mathrm{C} 18: 1 \mathrm{t} 10+\mathrm{t} 11$ & $4.57^{\mathrm{a}}$ & $3.25^{\mathrm{b}}$ & $4.47^{\mathrm{a}}$ & 0.222 & $* *$ \\
\hline C18:1 c9 & 24.7 & 25.7 & 26.4 & 1.11 & n.s. \\
\hline C18:1 c15 & $0.232^{c}$ & $0.468^{\mathrm{a}}$ & $0.309^{b}$ & 0.023 & $* * *$ \\
\hline CLA c9t11 & $1.32^{\mathrm{a}}$ & $0.676^{c}$ & $1.01^{b}$ & 0.091 & $* *$ \\
\hline CLA t10c12 & 0.100 & 0.084 & 0.101 & 0.006 & $\neq$ \\
\hline $\mathrm{CLA} \subset \mathrm{CC}$ & $0.013^{c}$ & $0.027^{a}$ & $0.019^{b}$ & 0.001 & $* * *$ \\
\hline CLA tt & 0.044 & 0.047 & 0.058 & 0.004 & $\neq$ \\
\hline C18:2 t11c15 & $0.359^{b}$ & $0.589^{a}$ & $0.548^{a}$ & 0.037 & ** \\
\hline C18:3 c9t11c15 & $0.196^{\mathrm{b}}$ & $0.267^{a}$ & $0.238^{\mathrm{ab}}$ & 0.017 & * \\
\hline C18:2 n-6 & $1.19^{b}$ & $2.35^{\mathrm{a}}$ & $0.862^{C}$ & 0.078 & $* * *$ \\
\hline C18:3 n-3 & $1.30^{\mathrm{b}}$ & $3.53^{\mathrm{a}}$ & $1.50^{\mathrm{b}}$ & 0.166 & $* * *$ \\
\hline Total OLCFA & 2.86 & 3.35 & 3.29 & 0.283 & n.s. \\
\hline Total BCFA & $2.91^{a}$ & $2.37^{b}$ & $2.74^{\mathrm{a}}$ & 0.110 & $* *$ \\
\hline Total PUFA & $4.63^{b}$ & $7.78^{\mathrm{a}}$ & $4.55^{b}$ & 0.287 & $* * *$ \\
\hline Total MUFA & 33.2 & 35.3 & 35.9 & 1.37 & n.s. \\
\hline Total SFA & 55.7 & 50.3 & 53.4 & 1.68 & n.s. \\
\hline$n-6 / n-3$ ratio & $1.18^{\mathrm{a}}$ & $0.733^{b}$ & $0.721^{b}$ & 0.052 & $* * *$ \\
\hline $\mathrm{P} / \mathrm{S}$ ratio & $0.046^{\mathrm{b}}$ & $0.125^{a}$ & $0.048^{b}$ & 0.005 & $* * *$ \\
\hline
\end{tabular}

a,b,c Means with different superscripts in the same row differ significantly $(P<0.05)$. n.s. not significantly different $(P>0.05)$.

${ }^{\dagger}$ Fatty acids abbreviation codes are as follows. Total OLCFA: sum of odd linear chain fatty acids: C13:0, C15:0, C17:0 and C17:1. Total BCFA: sum of branched chain fatty acids: iso $\mathrm{C} 12: 0$, anteiso $\mathrm{C} 12: 0$, iso $\mathrm{C} 13: 0$, anteiso $\mathrm{C13:0}$, iso $\mathrm{C14:0}$, anteiso $\mathrm{C14:0}$, iso $\mathrm{C15:0}$, anteiso $\mathrm{C15:0}$, iso $\mathrm{C16:0}$, anteiso $\mathrm{C} 16: 0$, iso $\mathrm{C} 17: 0$ and anteiso $\mathrm{C} 17: 0$. Total PUFA: sum of polyunsaturated fatty acids: C18:2 t11c15, C18:2 n-6, C18:3 n-6, C18:3 n-3, CLAc9t11, CLAt10c12, CLACc, CLAtt, C18:3 c9t11 15 and C20:2 $n-6$. Total MUFA: sum of monounsaturated fatty acids: C14:1 c9, C15:1, C16:1 t, C16:1 c9, C17:1, C18:1 t6-t8, C18:1 t9, C18:1 t10 + t11, C18:1 t12-t14, C18:1 c9, C18:1 c11, C18:1 c12, C18:1 c13, C18:1 c14 + t16, C18:1 c15 and C20:1. Total SFA: sum of saturated fatty acids: C10:0, C12:0, C13:0, C14:0, C15:0, C16:0, C17:0, C18:0, $\mathrm{C} 20: 0$ and $\mathrm{C} 22: 0$. $n-6 / n-3$ ratio: ratio between the sum of $C 18: 2 n-6, C 18: 3$ $n-6$ and $C 20: 2 n-6$, and C18:3 n-3. P/S ratio: ratio between the sum of C18:2 $n-6$ and C18:3 n-3, and the sum of C14:0, C16:0 and C18:0. FAME: fatty acids methyl esters.

${ }^{\ddagger}$ Approaching significance $(P<0.1)$.

\section{Discussion}

This study aimed to compare grazing pastures differing in botanical composition on FA metabolism in growing lambs. Stocking density was low and plant biomass was not limiting. Nevertheless, average daily weight gain of the BD pasture animals was very poor, most probably due the low intake of low digestible herbage, which could not guarantee energy requirements for growing lambs (CVB, 2004) and moreover the low protein content might also have impaired rumen microbial growth (Hume et al., 1970; Orkie et al., 1977). Significantly higher proportions of hydrogenation intermediates, particularly C18:1 t10 + t11,
Table 8 Total fatty acid content ( $\mathrm{mg} / \mathrm{g}$ meat) and fatty acid composition ( $\mathrm{g} / 100 \mathrm{~g}$ of FAME) of intramuscular fat of the animals grazing the three different pastures $(n=7)$

\begin{tabular}{|c|c|c|c|c|c|}
\hline & $\begin{array}{c}\text { Pasture } \\
\text { BD }\end{array}$ & L & IR & s.e. & Significance \\
\hline \multicolumn{6}{|l|}{ Fatty acids ${ }^{\dagger}$} \\
\hline Total & 16.0 & 24.4 & 19.6 & 2.58 & $\neq$ \\
\hline C12:0 & 0.288 & 0.179 & 0.212 & 0.040 & n.s. \\
\hline $\mathrm{C} 14: 0$ & 2.45 & 2.25 & 2.29 & 0.351 & n.s. \\
\hline C16:0 & $15.7^{\mathrm{b}}$ & $20.5^{\mathrm{a}}$ & $19.1^{a}$ & 0.829 & $* *$ \\
\hline C18.0 & 16.6 & 17.4 & 19.1 & 0.696 & $\neq$ \\
\hline $\mathrm{C} 18: 1 \mathrm{t}$ & 2.22 & 2.41 & 2.74 & 0.258 & n.s. \\
\hline C18:1 c9 & $22.8^{\mathrm{b}}$ & $28.9^{a}$ & $29.3^{a}$ & 1.13 & $* *$ \\
\hline C18:1 c15 & $0.170^{c}$ & $0.346^{\mathrm{a}}$ & $0.259^{b}$ & 0.025 & $* * *$ \\
\hline CLA c9t11 & 0.897 & 0.738 & 0.903 & 0.097 & n.s. \\
\hline CLA t10c12 & 0.045 & 0.047 & 0.052 & 0.006 & n.s. \\
\hline CLA cC & 0.042 & 0.064 & 0.052 & 0.006 & \\
\hline $\mathrm{CLA} t \mathrm{tt}$ & $0.061^{b}$ & $0.123^{a}$ & $0.093^{\mathrm{ab}}$ & 0.015 & * \\
\hline C18:3 c9t11c15 & 0.034 & 0.037 & 0.034 & 0.004 & n.s. \\
\hline C18:2 n-6 & $7.06^{\mathrm{a}}$ & $5.28^{\mathrm{b}}$ & $3.37^{c}$ & 0.564 & $* *$ \\
\hline C18.3n-3 & $2.64^{\mathrm{b}}$ & $3.99^{\mathrm{a}}$ & $2.59^{b}$ & 0.235 & ** \\
\hline$C 20: 4 n-6$ & $4.16^{\mathrm{a}}$ & $1.17^{\mathrm{b}}$ & $1.33^{\mathrm{b}}$ & 0.549 & ** \\
\hline$C 20: 5 n-3$ & $2.76^{\mathrm{a}}$ & $1.09^{b}$ & $1.33^{\mathrm{b}}$ & 0.315 & ** \\
\hline$C 22: 5 n-3$ & $2.69^{a}$ & $1.08^{b}$ & $1.26^{\mathrm{b}}$ & 0.296 & ** \\
\hline$C 22: 6 n-3$ & 0.427 & 0.293 & 0.340 & 0.037 & $\neq$ \\
\hline Total OLCFA & 2.04 & 2.37 & 2.12 & 0.128 & n.s. \\
\hline Total BCFA & $5.13^{\mathrm{a}}$ & $2.96^{\mathrm{b}}$ & $3.76^{\mathrm{b}}$ & 0.360 & $* *$ \\
\hline Total PUFA & $21.6^{\mathrm{a}}$ & $14.5^{\mathrm{b}}$ & $11.9^{\mathrm{b}}$ & 1.80 & ** \\
\hline Total MUFA & $28.9^{\mathrm{b}}$ & $35.0^{\mathrm{a}}$ & $35.6^{a}$ & 1.31 & ** \\
\hline Total SFA & $37.7^{\mathrm{b}}$ & $42.6^{a}$ & $43.0^{\mathrm{a}}$ & 1.32 & * \\
\hline$n-6 / n-3$ ratio & $1.37^{\mathrm{a}}$ & $1.05^{\mathrm{b}}$ & $0.902^{c}$ & 0.033 & $* * *$ \\
\hline $\mathrm{P} / \mathrm{S}$ ratio & $0.294^{a}$ & $0.233^{\mathrm{ab}}$ & $0.148^{b}$ & 0.029 & $* *$ \\
\hline
\end{tabular}

Indices for elongation and desaturation activity (calculated as ratios of $F A$ )

C20:4 n-6/C18:2 n-6 $0.543^{\mathrm{a}} \quad 0.393^{\mathrm{b}} \quad 0.219^{\mathrm{c}} 0.043 \quad * * *$

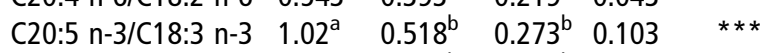
$\mathrm{C} 22: 5 \mathrm{n}-3 / \mathrm{C} 18: 3 \mathrm{n}-3 \quad 0.993^{\mathrm{a}} \quad 0.487^{\mathrm{b}} \quad 0.271^{\mathrm{b}} 0.094 \quad * * *$ C22:6 n-3/C18:3 n-3 $0.161^{\mathrm{a}} \quad 0.076^{\mathrm{b}} \quad 0.131^{\mathrm{a}} \quad 0.012 \quad * * *$ C22:5 n-3/C20:5 n-3 $0.991 \quad 1.00 \quad 0.944 \quad 0.036 \quad$ n.s. $\mathrm{C} 22: 6 \mathrm{n}-3 / \mathrm{C} 20: 5 \mathrm{n}-3 \quad 0.176^{\mathrm{b}} \quad 0.282^{\mathrm{a}} \quad 0.254^{\mathrm{a}} \quad 0.022 \quad$ **

\footnotetext{
$a, b, c$ Means with different superscripts in the same row differ significantly $(P<0.05)$. n.s. not significantly different $(P>0.05)$.

${ }^{\dagger}$ Fatty acids abbreviation codes are as follows. Total OLCFA: sum of odd linear chain fatty acids: C13:0, C15:0, C17:0 and C17:1. Total BCFA: sum of branched chain fatty acids: iso $\mathrm{C} 12: 0$, anteiso $\mathrm{C} 12: 0$, iso $\mathrm{C} 13: 0$, anteiso $\mathrm{C} 13: 0$, iso $\mathrm{C} 14: 0$, anteiso $\mathrm{C} 14: 0$, iso $\mathrm{C} 15: 0$, anteiso $\mathrm{C} 15: 0$, iso $\mathrm{C} 16: 0$, anteiso $\mathrm{C} 16: 0$, iso $\mathrm{C} 17: 0$ and anteiso C17:0. Total PUFA: sum of polyunsaturated fatty acids: C18:2 t11c15, C18:2 n-6, C18:3 n-6, C18:3 n-3, CLAc9t11, CLAt10c12, CLAcc, CLAtt, C18:3 c9t11c15 and C20:2 n-6. Total MUFA: sum of monounsaturated fatty acids: C14:1 c9, C15:1, C16:1 t, C16:1c9, C17:1, C18:1 t6-t8, C18:1 t9, C18:1 $\mathrm{t} 10+\mathrm{t} 11, \mathrm{C} 18: 1 \mathrm{t} 12-\mathrm{t} 14, \mathrm{C} 18: 1 \mathrm{c} 9, \mathrm{C} 18: 1 \mathrm{c11}, \mathrm{C} 18: 1 \mathrm{c12}, \mathrm{C} 18: 1 \mathrm{c13}, \mathrm{C} 18: 1$ $\mathrm{C} 14+\mathrm{t} 16, \mathrm{C} 18: 1 \mathrm{C} 15$ and C20:1. Total SFA: sum of saturated fatty acids:

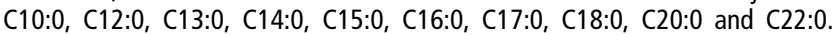
$n-6 / n-3$ ratio: ratio between the sum of $C 18: 2 n-6, C 18: 3 n-6$ and $C 20: 2 n-6$, and C18:3 n-3. P/S ratio: ratio between the sum of C18:2 n-6 and C18:3 n-3, and the sum of C14:0, C16:0 and C18:0. FAME: fatty acids methyl esters.

${ }^{\ddagger}$ Approaching significance $(P<0.1)$.
}

C18:2 t11 15 and CLA C9t11, were found in the rumen of animals grazing the BD pasture, despite the similar precursor supply for the different pastures. This suggests that other factors associated with BD pastures could provoke 
shifts in the rumen microbial population. Indeed, the different pastures were associated with different rumen fermentation patterns suggesting different microbial populations, which is in accordance with changes in rumen OBCFA (Figure 1). These FA have been suggested as rumen microbial markers (Vlaeminck et al., 2005). In this study, proportions of iso C17:0 were particularly increased in the rumen contents of $\mathrm{BD}$ pasture animals compared with the other groups $(0.133 \%$ of FAME $v .0 .088$ and $0.071 \%$ of FAME for BD $v$. L and IR pasture animals, respectively, $P=0.019)$. From their literature survey, Vlaeminck et al. (2006) observed a positive correlation between iso C17:0 and C18:1 t11, from which they suggested group B bacteria, responsible for the final hydrogenation step, to have lower iso C17:0 proportions. These suggested shifts in rumen microbial populations of $B D$ pasture animals might have provoked the observed changes in rumen biohydrogenation intermediates, which we are currently investigating further.

Another important finding in this study was the significantly higher proportions of C18:2 n- 6 and C18:3 n-3 in the abomasum contents and subcutaneous fat but not in the rumen contents of the $L$ pasture animals. Differences in abomasum and subcutaneous fat suggest an increased duodenal flow of these PUFA, which might be induced either by reduced lipolysis through (physical) protection of the FA, by a (partial) inhibition of microbial lipases or by reduced microbial 'contact time' due to for e.g. higher outflow rates which might be the most probable reason. Indeed, the former are unlikely as differences in C18:2 $n-6$ and $\mathrm{C} 18: 3 \mathrm{n}-3$ proportions should then be obvious in the rumen also, which is not the case. Moreover, increased rumen outflow rates have been reported before for clover rich diets (Dewhurst et al., 2003a and b; Lee et al., 2003). Although our experimental design did not allow a quantitative evaluation of abomasal flows and rumen and abomasum contents have been sampled at one single time point at slaughter, this approach revealed valuable for a qualitative assessment of the rumen FA metablosim.

Animals presented a low total amount of FA in the subcutaneous fat, compared with results of Enser et al. (1996), Wachira et al. (2002) and Cooper et al. (2004). This is most probably related to contamination of the subcutaneous fat by connective tissue. Concerning the FA metabolism, it is widely known that subcutaneous fat is more responsive to changes in the dietary FA supply or changes in rumen metabolism than the intramuscular fat (Wachira et al., 2002; Demirel et al., 2004). This was also observed in the present study. Moreover, differences in intramuscular fat content additionally might complicate interpretation. Intramuscular fat of the BD pasture animals presented the highest proportions for most of the PUFA, in agreement withAdnøy et al. (2005), who reported higher proportions of PUFA in intramuscular fat of lambs grazing mountain pastures, with a higher botanical diversity, than cultivated lowland pastures. Particularly, higher proportions of C20:4 n-6, C20:5 n-3 and C22:5 n-3 in intramuscular fat of the BD pasture animals were observed. Furthermore, indices for elongation and desaturation activity suggested some stimulation of the process involved in the production of these long-chain PUFA in muscle. Nevertheless, a confounding effect with the lower intramuscular fat content of these animals and associated higher phospholipid/triacylglycerol ratios and long-chain PUFA proportion cannot be excluded. This is confirmed by the considerably lower levels of C18:1 c9 in intramuscular fat of BD pasture animals compared with the other pasture groups. Indeed, oleic acid is the major FA present in the non-phospholipid fraction of meat, and proportions of oleic acid in the triacylglycerol and the polar lipid fraction were shown to increase with increasing fatness in beef cattle (Itoh et al., 1999; Kazala et al., 1999). Obviously, the current experimental design only gives some indications of possible effects on rumen and intramuscular FA metabolism as induced by botanically diverse pasture grazing. These effects and the interference with e.g. fat deposition merit further investigation.

From this study, we suggest that grazing different pastures induced changes in the rumen microbial population, which are most likely the reason for differences in biohydrogenation of PUFA. Furthermore, grazing a more diverse pasture might affect intramuscular FA metabolism as suggested from indices of PUFA desaturation and elongation, although differences between treatments in terms of absolute fat deposition might have provoked some confounding effect. Finally, higher PUFA proportions in abomasum, subcutaneous and intramuscular fat were observed in lambs grazing a leguminous rich pasture.

\section{Acknowledgements}

Results were presented at the Fourth EuroFed Lipid Congress, 1 - 4 October 2006, Madrid, Spain (Lourenço, M, Van Ranst, G, De Smet, S, Raes, K, Fievez, V. "Grazing botanically diverse pastures induces differences in rumen fatty acid metabolism and intramuscular and subcutaneous lamb fat"). The results were also partially presented at the $52^{\text {nd }}$ ICOMST, $13-18$ August 2006, Dublin, Ireland (Lourenço, M, Van Ranst, G, De Smet, S, Raes, K, Fievez, V. "Grazing botanically diverse pastures influences tissue long-chain fatty acid profile in lambs").

$\mathrm{PhD}$ grant of $\mathrm{M}$. Lourenço funded by the Foundation for Science and Technology - Portugal. Financial support of this experiment by IWT - Institute for the Promotion of Innovation by Science and Technology in Flanders. Technical assistance of Sabine Coolsaet, Erik Claeys and Stefaan Lescouhier. Ludo Van Alphen for providing the lambs and the pastures where this experiment took place.

\section{References}

Ådnøy T, Haug A, Sørheim 0, Thomassen MS, Varszegi Z and Eik LO 2005. Grazing on mountain pastures - does it affect meat quality in lambs? Livestock Production Science 94, 25-31.

Cabiddu A, Decandia M, Addis M, Piredda G, Pirisi A and Molle G 2005. Managing Mediterranean pastures in order to enhance the level of beneficial fatty acids in sheep milk. Small Ruminant Research 59, 169-180. 
Chow TT, Fievez V, Moloney AP, Raes K, Demeyer D and De Smet S 2004. Effect of fish oil on in vitro rumen lipolysis, apparent biohydrogenation of linoleic acid and linolenic acid and accumulation of biohydrogenation intermediates. Animal Feed Science and Technology 117, 1-12.

Collomb M, Bütikofer U, Sieber R, Bosset JO and Jeangros B 2001. Conjugated linoleic acid and trans fatty acid composition of cows' milk fat produced in lowlands and highlands. Journal of Dairy Research 68, 519-523.

Collomb M, Bütikofer U, Sieber R, Jeangros B and Bosset JO 2002a. Composition of fatty acids in cow's milk fat produced in the lowlands, mountains and highlands of Switzerland using high-resolution gas chromatography. International Dairy Journal 12, 649-659.

Collomb M, Bütikofer U, Sieber R, Jeangros B and Bosset JO 2002b. Correlation between fatty acids in cow's milk fat produced in the lowlands, mountains and highlands of Switzerland and botanical composition of the fodder. International Dairy Journal 12, 661-666.

Cooper SL, Sinclair LA, Wilkinson RG, Hallett KG, Enser M and Wood JD 2004. Manipulation of the n-3 polyunsaturated fatty acid content of muscle and adipose tissue in lambs. Journal of Animal Science 82, 1461-1470.

CVB 2004. Table Booklet Animal Nutrition 2004. Feed requirements of farm animals and nutritional value characteristics. Central Bureau for Livestock Feeding, Lelystad, pp. 110 (in Dutch), PRLT, Food and Agribusiness Communicatie, Zoetermeer.

De Vries D 1933. The ranking method, an estimation method for botanical grassland research with determination of ranking order. Verslagen van Landbouwkundige Onderzoekingen, 'S Gravenhage, The Netherlands, $n^{\circ} 39 \mathrm{~A}$ (in Dutch).

Demirel G, Wachira AM, Sinclair LA, Wilkinson RG, Wood JD and Enser M 2004. Effects of dietary n-3 polyunsaturated fatty acids, breed and dietary vitamin $\mathrm{E}$ on the fatty acids of lamb muscle, liver and adipose tissue. British Journal of Nutrition 91, 551-565.

Dewhurst RJ, Evans RT, Scollan ND, Moorby JM, Merry RJ and Wilkins RJ 2003a. Comparison of grass and legume silages for milk production. 2. In vivo and in sacco evaluations of rumen function. Journal of Dairy Science 86 , 2612-2621.

Dewhurst RJ, Fisher WJ, Tweed JKS and Wilkins RJ 2003b. Comparison of grass and legume silages for milk production. 1. Production responses with different levels of concentrate. Journal of Dairy Science 86, 2598-2611.

Enser M, Hallett K, Hewitt B, Fursey GAJ and Wood JD 1996. Fatty acid content and composition of English beef, lamb and pork at retail. Meat Science $42,443-456$.

European Community 1993. Determination of crude protein. Directive $\mathrm{n}^{\circ}$ L179/9 of the Commission of the European Communities of 22.07.93. Official Journal European Community, Brussels, pp. 8-10.

Hume ID, Miror RJ and Somers M 1970. Synthesis of microbial protein in the rumen. 1. Influence of the level of nitrogen intake. Australian Journal of Agricultural Research 21, 283-296.

Itoh M, Johnson CB, Cosgrove GP, Muir PD and Purchas RW 1999. Intramuscular fatty acid composition of neutral and polar lipids for heavy-weight
Angus and Simmental steers finished on pasture or grain. Journal of the Science of Food and Agriculture 79, 821-827.

Kazala EC, Lozeman FJ, Mir PS, Laroche A, Bailey DRC and Weselake RJ 1999. Relationship of fatty acid composition to intramuscular fat content in beef from crossbred Wagyu cattle. Journal of Animal Science 77, 1717-1725.

Lee MRF, Harris LJ, Dewhurst RJ, Merry RJ and Scollan ND 2003. The effect of clover silages on long chain fatty acid rumen transformations and digestion in beef steers. Animal Science 76, 491-501.

Lourenço $\mathrm{M}$ and Fievez V 2005. Content, pattern and esterification of fatty acids in fresh grass in relation to extraction solvents and sample storage conditions. In Proceedings, XX International Grassland Congress, Dublin, Ireland, p. 183, Wageningen Academic Press, Wageningen.

Lourenço M, Vlaeminck B, Bruinenberg M, Demeyer D and Fievez V 2005. Milk fatty acid composition and associated rumen lipolysis and fatty acid hydrogenation when feeding forages from intensively managed or semi-natural grasslands. Animal Research 54, 471-484.

Madeira de Carvalho LM 2002. Epidemiologia e controlo da estrongilidose em diferentes sistemas de produção equina em Portugal, PhD thesis, Faculty of Veterinary Medicine, Technical University of Lisbon, Portugal.

Orkie AU, Buttery PJ and Lewis D 1977. Ammonia concentration and protein synthesis in the rumen. Proceedings of the Nutrition Society 36, 38-49.

Raes K, De Smet S and Demeyer D 2001. Effect of double-muscling in Belgian-Blue young bulls on the intramuscular fatty acid composition with emphasis on conjugated linoleic acid and polyunsaturated fatty acids. Animal Science 73, 253-260.

Raes K, Haak L, Balcaen A, Claeys E, Demeyer D and De Smet S 2004. Effect of linseed feeding at similar linoleic acid levels on the fatty acid composition of double-muscled Belgian-Blue young bulls. Meat Science 66, 307-315.

Van Nevel CJ and Demeyer DI 1977. Effect of monesin on rumen metabolism in vitro. Applied Environment Microbiology 34, 251-257.

Van Soest PJ and Wine RH 1968. The determination of lignin and cellulose in acid detergent fiber with permanganate. Journal of the Association of Official Analytical Chemists 51, 780-785.

Van Soest PJ, Robertson JB and Lewis BA 1991. Methods for dietary fiber, neutral detergent fiber and nonstarch polysaccharides in relation to animal nutrition. Journal of Dairy Science 74, 3583-3597.

Vlaeminck B, Dufour C, Van Vuuren AM, Cabrita AMR, Dewhurst RJ, Demeyer D and Fievez V 2005. Potential of odd and branched chain fatty acids as microbial markers: evaluation in rumen contents and milk. Journal of Dairy Science 88, 1031-1041.

Vlaeminck B, Fievez V, Cabrita ARJ, Fonseca AJM and Dewhurst RJ 2006. Factors affecting odd and branched chain fatty acids in milk: a review. Animal Feed Science and Technology 131, 389-417.

Wachira AM, Sinclair LA, Wilkinson RG, Enser M, Wood JD and Fisher AV 2002. Effects of dietary fat source and breed on the carcass composition, n-3 polyunsaturated fatty acid and conjugated linoleic acid content of sheep meat and adipose tissue. British Journal of Nutrition 88, 697-709. 